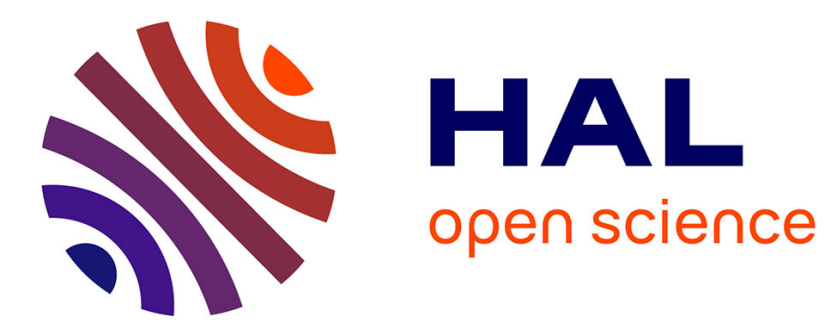

\title{
Martensitic Transformation in Microcrystalline Melt-Quenched Fe-Ni Alloys
}

\author{
A. Glezer, M. Pankova
}

\section{To cite this version:}

A. Glezer, M. Pankova. Martensitic Transformation in Microcrystalline Melt-Quenched Fe-Ni Alloys. Journal de Physique IV Proceedings, 1995, 05 (C8), pp.C8-299-C8-303. 10.1051/jp4:1995842 jpa00254091

\section{HAL Id: jpa-00254091 https://hal.science/jpa-00254091}

Submitted on 1 Jan 1995

HAL is a multi-disciplinary open access archive for the deposit and dissemination of scientific research documents, whether they are published or not. The documents may come from teaching and research institutions in France or abroad, or from public or private research centers.
L'archive ouverte pluridisciplinaire HAL, est destinée au dépôt et à la diffusion de documents scientifiques de niveau recherche, publiés ou non, émanant des établissements d'enseignement et de recherche français ou étrangers, des laboratoires publics ou privés. 


\title{
Martensitic Transformation in Microcrystalline Melt-Quenched Fe-Ni Alloys
}

\author{
A.M. Glezer and M.N. Pankova \\ Institute of Physical Metallurgy, 107005 Moscow, Russia
}

\begin{abstract}
The features of martensite transformation in $\mathrm{Fe}-(31-32) \%$ Ni melt-quenched alloys are considered. The meltquenching was realized by spinning technique with variable parameters. The influence of the melt-quenching on structural and kinetics transformation parameters is revealed. In particular $\mathrm{M}_{\mathrm{s}}$ point is shown to decrease but volume percentage of athermal martensite is found to be invariable with austenite grain size change.
\end{abstract}

\section{INTRODUCTION}

The size of austenite grain is of great importance for the proceeding of martensite transformation. There are only several references in which there was estimated the influence of austenite grain size on the martensite point $M_{S}$ and structure of transformation product [1-3]. Refining of austenite grain from 100 to $7 \mu \mathrm{m}$, in the alloys $\mathrm{Fe}-(1-15 \%) \mathrm{Ni}$ with primarily lath morphology of thermally transformed martensite does not vary the $\mathrm{M}_{\mathrm{S}}$ temperature [1]. In the alloy $\mathrm{Fe}-30,8 \% \mathrm{Ni}-0,005 \% \mathrm{C}$ the $\mathrm{M}_{\mathrm{S}}$ temperature was decreased from $-44^{\circ} \mathrm{C}$ to $-77^{\circ} \mathrm{C}$ at the change of grain size from 54 to $17 \mu \mathrm{m}$ [3]. Unfortunately, authors of $[2,3]$ studied neither kinetics nor volume percentage of martensite transformation in fine-grained samples.

There should be noted the absence of the papers on the investigations of peculiarities of martensite transformation in microcrystalline alloys. To fill in this gap we had formulated the problem of the production of superfine grain in the alloys of Fe-Ni system well-known from the point of view of morphology of the thermally transformed martensite and investigation of the influence of microcrystalline state on kinetics and morphological peculiarities of martensite transformation at the cooling were done.

\section{EXPERIMENTAL METHODS AND SAMPLE PREPARATION}

The quenching from the melt is one of the most effective methods of superfine grain production. Two alloys: $\mathrm{Fe}-31 \% \mathrm{Ni}$ and $\mathrm{Fe}-32 \% \mathrm{Ni}$ which were in microcrystalline state at the room temperature after the quenching from the melt and possessed $M_{S}$ point lower than room temperature were chosen.

The ribbons of the alloys were produced by spinning method in inert gas atmosphere. Geometrical parameters of the ribbons produced in the same technological conditions are the following: width is 5-6 $\mathrm{mm}$, thickness - 50-60 $\mu \mathrm{m}$, Vacuum heat treatment of the ribbons was carried out in temperature interval $800-1200^{\circ} \mathrm{C}$ during 1 hour. The rate of cooling with furnace was $5-10^{\circ} \mathrm{C} / \mathrm{min}$.

Light and transmission electron microscopy, $X$-ray analysis and Auger-spectroscopy were used as the main methods of the investigation. 


\section{RESULTS}

At the room temperature rapidly quenched alloy $\mathrm{Fe}-32 \%$ Ni has average austenite grain size of $2,3 \mu \mathrm{m}$, The average austenite grain size was determined on the histograms using STATGRAFICS computer program. The kinetics of the growth of austenite grain average size at the annealing temperature has the view common for rapidly quenched Fe-based alloys [4]. The grain size is on the level of $2,3 \mu \mathrm{m}$ up to the annealing temperature $900^{\circ} \mathrm{C}$, and then it increases sharply up to $8 \mu \mathrm{m}$. at the annealing temperature $1000^{\circ} \mathrm{C}$ and up to $10,7 \mu \mathrm{m}$ at $1100^{\circ} \mathrm{C}$.

To obtain the dependence of martensite transformation degree on grain size the ribbon samples annealed at the temperatures $800-1200^{\circ} \mathrm{C}$ during 1 hour were sharply put into liquid nitrogen. The same cooling rate in all the cases allowed to rely on the obtaining of martensite of the same morphological type in all the samples. The amount of martensite being formed was determined on the contact ribbon surface which was in contact with the cooling disk during spinning process and on the free ribbon surface which was not in contact. That is represented in Fig.1 the curve of the dependence of volume percentage of austenite transformed in temperature interval from $M_{S}$ to $-196^{\circ} \mathrm{C}$ in surface layer of contact and free sides of the ribbon depending on the annealing temperature. It is shown that volume percentage of martensite transformation depends on the annealing temperature (austenite grain size), though in reality on the different sides of the ribbon there are two different regularities observed on contact side (curve 1) the volume percentage of martensite transformation is close to $90 \%$ and it depends weakly on grain size and annealing temperature, and on the free surface there sharp dependence on annealing temperature is observed (curve 2). It can mean that martensite transformation on the contact side is practically ceased up to the temperature $-196^{\circ} \mathrm{C}$ in the grains of any size from 1 to $30 \mathrm{p}$ and on the free side it is at different stages of the development depending on grain size. It should be noted that the character of the dependence of 1 and 2 curves on the annealing temperature is the same one: both of them reach saturation, beginning from the annealing temperature $1100^{\circ} \mathrm{C}$ for curve 1 and $1200^{\circ} \mathrm{C}$ for curve 2 . In other words, the volume percentage of transformed austenite does not depend on its size beginning from some certain austenite grain size.

The fact, that at the same average grain size the martensite transformation degree on the surface of the different sides is different, stipulates that the initial temperatures of the martensite transformation starting on contact and free ribbon surface are different. Our experiments show that $\mathbf{M}_{\mathbf{S}}$ temperature at the contact side is higher than at the free one. Moreover the transformation interval can be realized completely at the contact surface but cannot at the free surface even up to the lowest temperature of the measurement $\left(-196^{\circ} \mathrm{C}\right)$. As it has been shown in Auger-spectroscopy experiments the difference of martensite points on contact and free sides of the ribbons is connected with the difference of Ni concentration on the contact and on the free ribbon surface. The concentration of $\mathrm{Ni}$ at the contact surface almost corresponds to the alloy composition but at the free surface it is significantly higher. The composition of the ribbons is equalized at the annealing mode $1100-1200^{\circ} \mathrm{C}$ during 1 hour; the convergence of the curves 1 and 2 in Fig. 1 is evidence of this fact.

Martensite transformation takes place in the grains of all the observed sizes from 1 to $30 \mu \mathrm{m}$. at the dipping into liquid nitrogen with the rate $200 \mathrm{\circ} / \mathrm{s}$ of ribbon samples of rapidly quenched $\mathrm{Fe}-31 \% \mathrm{Ni}$ and $\mathrm{Fe}-32 \% \mathrm{Ni}$ alloys. Martensite crystals on both sides of the ribbon are of the same morphological type. They have lenticular form and are arranged in acute angle zigzag groups. These groups look similar both on microsection and on electron microscopic image. There is observed the midrib consisting of the twins of (112) system characteristic of $\alpha$-martensite. It is known that this type of the martensite is formed with athermal kinetics [5]. It should be noted that in superfine grain the lightninglike groups of martensite crystals are placed from one grain boundary to another one and due to small grain size they have the ratio of plate thickness to its length equal to 1 , and they have rather long line of neighbouring crystal coincidence (Fig.2). It allows to increase the volume of martensite phase in the grain and to obtain in the whole sample near the temperature of the martensite transformation finishing the volume percentage of martensite close to one in coarse-grained material (see curve 1 in Fig. 1).

For the solution of the problem of the influence of fine and superfine grain on the initial temperature of martensite transformation there has been chosen the alloy $\mathrm{Fe}-31 \% \mathrm{Ni}$, martensite point of which is $-50^{\circ} \mathrm{C}$ 


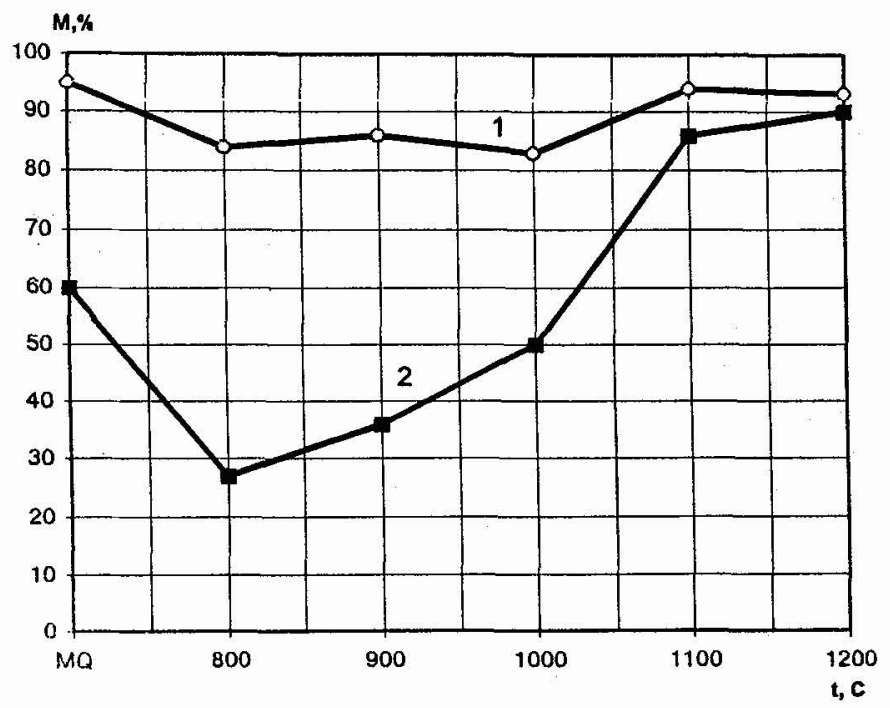

Figure 1: The dependence of austenizing temperature (annealing time - $1 \mathrm{~h}$.) on the volume percentage of martensite in Fe$32 \% \mathrm{Ni}$ melt-quenched alloy near contact (curve 1) and free (curve 2) specimen surface.

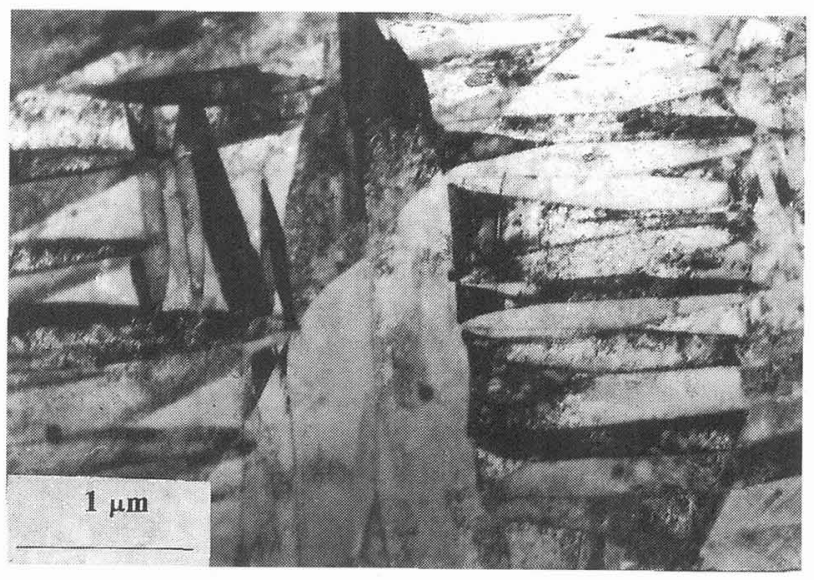

Figure 2: The bright field electron micrograph of the athermal matrensite structure formed in the middle area of the meltquenched $\mathrm{Fe}-31 \% \mathrm{Ni}$ ribbon. 
in coarse-grained sample. As the nickel microsegregation takes place after the quenching from the melt, the ribbon samples were grinded from the side of free surface up to $30 \mu \mathrm{m}$ thickness and then were annealed in the vacuum furnace according the same modes as it was made for the alloy $\mathrm{Fe}-32 \% \mathrm{Ni}$. The kinetics of the growth of austenite grain in rapidly quenched alloy $\mathrm{Fe}-31 \% \mathrm{Ni}$ was approximately the same as in $\mathrm{Fe}-32 \% \mathrm{Ni}$ one. The martensite beginning of transformation was controlled by the appearance of the relief on the polished microsection surface, and martensite point was measured by the thermometer dipped into the solution of alcohol with liquid nitrogen. After the appearance of the first portions of martensite the sample was sharply dipped into liquid nitrogen and after this the volume percentage of the martensite transformation was determined by X-ray method.

The curve of the dependence of initial temperature and volume percentage of martensite transformation on grain size in microcrystalline alloy Fe-31\% $\mathrm{Ni}$ is represented in Fig. 3. It shows that at the decrease of the austenite grain size from 11 to $2 \mu \mathrm{m}$ the temperature of athermal transformation starting is decreased from -85 to $-110^{\circ} \mathrm{C}$, and volume percentage of the martensite formed in temperature interval from $\mathrm{M}_{\mathrm{S}}$ to $-196^{\circ} \mathrm{C}$ is decreased from 70 to $30 \%$ together with this temperature. The last fact does not contradict to the above-mentioned conclusion about the independence of the austenite grain size on the transformed volume fraction because the temperature of the end of transformation is below the lowest temperature of the cooling experiment $\left(-196^{\circ} \mathrm{C}\right)$. In this case the width of martensite transformation interval and therefore the volume fraction of martensite phase vary essentially with the austenite grain size just in the same manner as $M_{S}$ point does as can be clearly seen in Fig. 3 .

Thus, the austenite grain size influences the $\mathbf{M}_{\mathfrak{S}}$ temperature of the alloys with the athermal transformation kinetics but does not influence the volume fraction of martensite phase if the transformation interval can be completely realized during the cooling experiment.



Figure 3: The dependence of average grain size on the $\mathrm{M}_{\mathrm{s}}$ point (curve 1,2) and on the volume percentage of martensite (curve 3) in Fe-31\%Ni alloy; 1-melt-quenching experiments (given work), 2-solid state quenching experiments [3] 


\section{acknowledgements}

The research described in this publication was made possible in part by Grant N M7R300 from the International Science Foundation and Russian Government.

\section{References}

[1] Schastlivcev V.M.,Mirzaev D.A., Yakovleva I.L., Structure of heat treatment steel (Metallurgiya, Moscow, 1994) pp.74-77.

[2] Fawzy.H.S., J.Mater.Sci., Volume 22 (1987) 3885-3892.

[3] Tamura 1.,Yamoka J.,"Strength and ductility of two-phase iron alloy composed of austenite and martensite", Mech.Behav.Mater.,Kuoto, 1971, (Kyoto, 1972), Volume b pp.31-38.

[4] Sosnin V.V., Glezer A.M., Zigalina O.M. "Structure of microcrystalline Ni-Fe alloys", 7-th Int.Conf. Rep.Quench.Met., Stockholm, 1990, p.OLO35.

[5] Kurdumov G.V.,Utevskiy L.M.,Entin R.I.,Transformations in iron and steel (Nauka, Moscow, 1977), pp.66-91. 